\title{
Strong convergence of Picard and Mann iterations for strongly demicontractive multi-valued mappings
}

\section{PACHARA JAILOKA ${ }^{1}$, VAsile Berinde ${ }^{2}$ and SutheP SUANTAi ${ }^{1}$}

\begin{abstract}
.
A class of demicontractive mappings was first introduced in [Hicks, T. L. and Kubicek, J. D., On the Mann iteration process in a Hilbert space, J. Math. Anal. Appl., 59 (1977) 498-504 and Măruşter, Ş., The solution by iteration of nonlinear equations in Hilbert spaces, Proc. Amer. Math. Soc., 63 (1977), 69-73] and was first mentioned in the case of multi-valued mappings in [Chidume, C. E., Bello, A. U. and Ndambomve, P., Strong and $\Delta$-convergence theorems for common fixed points of a finite family of multivalued demicontractive mappings in CAT(0) spaces, Abstr. Appl. Anal., 2014 (2014), https://doi.org/10.1155/2014/805168 and Isiogugu, F. O. and Osilike, M. O., Convergence theorems for new classes of multivalued hemicontractive-type mappings, Fixed Point Theory Appl., 2014 (2014), https://doi.org/10.1186/1687-1812-2014-93]. The demicontractivity with some weak smoothness conditions ensures only weak convergence of Mann iteration. In 2015, Măruşter and Rus [Kannan contractions and strongly demicontractive mappings, Creat. Math. Inform., 24 (2015), No. 2, 173-182], introduced a class of strongly demicontractive mappings, and also discussed some relationships between strongly demicontractive mappings and Kannan contractions. In this paper, we introduce a new class of strongly demicontractive multi-valued mappings in Hilbert spaces. Strong convergence theorems of Picard and Mann iterative methods for strongly demicontractive multi-valued mappings are established under some suitable coefficients and control sequences.
\end{abstract}

Acknowledgments. The authors would like to thank the referees for valuable comments and suggestions for improving this work. S. Suantai would like to thank Chiang Mai University for the financial support.

\section{REFERENCES}

[1] Akuchu, B. G., Strong convergence of the Mann sequence for demicontractive maps in Hilbert spaces, Adv. Fixed Point Theory, 4 (2014), No. 3, 415-419

[2] Berinde, V., Approximating fixed points of weak contractions using the Picard iterations, Nonlinear Anal. Forum, 9 (2004), No. 1, 43-53

[3] Chidume, C. E., Bello, A. U. and Ndambomve, P., Strong and $\Delta$-convergence theorems for common fixed points of a finite family of multivalued demicontractive mappings in CAT(0) spaces, Abstr. Appl. Anal., 2014 (2014), https://doi.org/10.1155/2014/805168

[4] Chidume, C. E. and Măruşter, Ş., Iterative methods for the computation of fixed points of demicontractive mappings, J. Comput. Appl. Math., 234 (2010), 861-882

[5] De la Sen, M., Some combined relations between contractive mappings, Kannan mappings, reasonable expansive mappings, and T-stability, Fixed Point Theory Appl., Hindawi Publ. Corp., 2009, Art. ID 815637

[6] Hicks, T. L. and Kubicek, J. D., On the Mann iteration process in a Hilbert space, J. Math. Anal. Appl., 59 (1977), 498-504

[7] Hanjing, A. and Suantai, S., Solving split equality common fixed point problem for infinite families of demicontractive mappings, Carpathian J. Math., 34 (2018), No. 3, 321-331

Received: 24.06.2019; In revised form: 27.04.2020; Accepted: 04.05.2020

2010 Mathematics Subject Classification. 47H04, 47H10, 47J25.

Key words and phrases. Fixed points, Picard iteration, Mann iteration, strongly demicontractive mappings, multivalued mappings, strong convergence.

Corresponding author: Suthep Suantai; suthep.s@cmu.ac.th 
[8] Isiogugu, F. O. and Osilike, M. O., Convergence theorems for new classes of multivalued hemicontractive-type mappings, Fixed Point Theory Appl., 2014 (2014), https:/ / doi.org/10.1186/1687-1812-2014-93

[9] Jailoka, P. and Suantai, S., Split common fixed point and null point problems for demicontractive operators in Hilbert spaces, Optim. Methods Softw., 34 (2019), No. 2, 248-263

[10] Jailoka, P. and Suantai, S., The split common fixed point problem for multivalued demicontractive mappings and its applications, Rev. R. Acad. Cienc. Exactas Fís. Nat. Ser. A Math. RACSAM, 113 (2019), No. 2, 689-706

[11] Kannan, R., Some results on fixed points, Bull. Calcutta. Math. Soc., 60 (1968), 71-76

[12] Măruşter, Ş., Sur le calcul des zeros d'un operateur discontinu par iteration, Canad. Math. Bull., 16 (1973), No. 4, 541-544

[13] Măruşter, S.., The solution by iteration of nonlinear equations in Hilbert spaces, Proc. Amer. Math. Soc., 63 (1977), 69-73

[14] Moudafi, A., The split common fixed-point problem for demicontractive mappings, Inverse Problems, 26 (2010), $587-600$

[15] Măruşter, L. and Măruşter, Ş., Strong convergence of the Mann iteration for $\alpha$-demicontractive mappings, Math. Comput. Modelling, 54 (2011), 2486-2492

[16] Măruşter, Ş. and Rus, I. A., Kannan contractions and strongly demicontractive mappings, Creat. Math. Inform., 24 (2015), No. 2, 173-182

[17] Osilike, M.O., Stability results for fixed point iteration procedures, J. Nigerian Math. Soc., 14/15 (1995/96), 17-29

[18] Qing, Y. and Rhoades, B. E., T-stability of Picard iteration in metric spaces, Fixed Point Theory Appl., Hindawi Publ. Corp., 2008, Art. ID 418971

[19] Shehu, Y. and Cholamjiak, P., Another look at the split common fixed point problem for demicontractive operators, Rev. R. Acad. Cienc. Exactas Fís. Nat. Ser. A Mat., 110 (2016), 201-218

[20] Yao, Y., Yao, J. C., Liou, Y. C. and Postolache, M., Iterative algorithms for split common fixed points of demicontractive operators without priori knowledge of operator norms, Carpathian J. Math., 34 (2018), No. 3, 459-466

\author{
${ }^{1}$ Department of Mathematics, Faculty of Science \\ CHIANG MAI UNIVERSITY \\ Research CENTER IN MATHEMATiCs AND Applied Mathematics \\ CHIANG MAI 50200, THAILAND \\ E-mail address: pachara.j4@gmail.com \\ E-mail address: suthep.s@cmu.ac.th \\ ${ }^{2}$ Department of Mathematics And COMPUter SCience \\ NORTH UNIVERSITY CENTER AT BAIA MARE \\ TECHNICAL UNIVERSITY OF CLUJ-NAPOCA \\ VICTORIEI 76, BAIA MARE 430122, ROMANIA \\ E-mail address: vberinde@cunbm.utcluj.ro
}

